\title{
Characteristics of Turbinaria conoides and Padina Minor As Raw Materials For Healthy Seaweed Salt
}

\author{
Nurjanah ${ }^{1, *}$, Asadatun Abdullah', Seftylia Diachanty ${ }^{1,2}$
}

Nurjanah ${ }^{1, *}$, Asadatun Abdullah', Seftylia Diachanty ${ }^{1,2}$

'Department of Aquatic Product Technology, Faculty of Fisheries and Marine Sciences, IPB University (Bogor Agricultural University), Darmaga Campus of IPB, Jalan Agatis, Bogor 16680 West Java, INDONESIA.

${ }^{2}$ Department of Aquatic Product Technology, Faculty of Fisheries and Marine Sciences, Mulawarman University, INDONESIA.

\section{Correspondence}

Nurjanah

Department of Aquatic Product Technology, Faculty of Fisheries and Marine Sciences,

IPB University (Bogor Agricultural

University), Darmaga Campus of IPB, Jalan Agatis, Bogor 16680 West Java, INDONESIA.

E-mail: nurjanahthp@gmail.com

History

- Submission Date: 18-02-2020;

- Review completed: 01-03-2020;

- Accepted Date: 16-03-2020.

DOI : 10.5530/pj.2020.12.93

Article Available online http://www.phcogj.com/v12/i3

\section{Copyright}

(C) 2020 Phcogj.Com. This is an openaccess article distributed under the terms of the Creative Commons Attribution 4.0 International license.

\section{ABSTRACT}

Background: Seaweed is one of the abundant biological resources in Indonesia and contains secondary metabolites. This study was aimed to determine the characteristics and antioxidant activity of brown seaweed salts that fits the standard hence it can be applied as a functional salt preparation for hypertensive patients. Objective: The study consisted of identification of raw materials, yield analysis, the levels of $\mathrm{Na}$ and $\mathrm{K}$, heavy metals, $\mathrm{NaCl}$ and antioxidant activities using the Ferric Reducing Antioxidant Power (FRAP) and the Cupric Reducing Antioxidant Capacity (CUPRAC) methods. Materials and Methods: The experimental design used was a Completely Randomized Design (CRD) with different types of seaweed as a parameter (Turbinaria conoides and Padina minor), temperature $\left(40^{\circ} \mathrm{C}\right.$ and $55^{\circ} \mathrm{C}$ ), and time (10 and 30 minutes) with 3 replications. Results: The results demonstrated the interaction between different types of seaweed, temperature and heating time had a significant effect on the level of $5 \%(P<0.05)$ on yield, the ratio of $\mathrm{Na}: \mathrm{K}$ and functional salt $\mathrm{NaCl}$. A functional salt FRAP antioxidant activity of $T$. conoides ranged from 39.12 to $55.31 \mu \mathrm{M}$ trolox/g and CUPRAC ranged from 98.50 to $113.95 \mu \mathrm{M}$ trolox/g, while the functional salt from $P$. minor has FRAP antioxidant activity ranging from 18.19 to $24.67 \mu \mathrm{M}$ trolox/g and CUPRAC 40.05-53.05 $\mu \mathrm{M}$ trolox/g. Conclusion: Seaweed T. conoides and $P$. minor can be used as raw materials for functional salt preparations for hypertensive patients.

Key words: CUPRAC, DPPH, FRAP, Functional salt, Hypertension.

\section{INTRODUCTION}

Seaweed is one of the abundant biological resources in Indonesian water. Based on data from the Ministry of Marine Affairs and Fisheries (MMAF) in 2016 seaweed production reached 11.69 million tons. ${ }^{1}$ The use of seaweed in the industry today prefers using red seaweed (Eucheuma cottonii, E. spinosum, and Gracilaria sp.) and green seaweed (Caulerpa racemosa, C. lentilifera and Ulva lactuca ), while brown seaweed is limited to extract of alginate content. The most abundant brown seaweed in Indonesian sea is Turbinaria sp., Sargassum sp. and Padina sp.

Brown seaweed produces varieties secondary metabolites such as alkaloids, terpenoids, steroids, tannins, saponins, and glycosides that have a potency in the pharmaceutical industry. ${ }^{2}$ It also has the inhibitory activity againts LDL oxidation, Angiotensin Converting Enzyme (ACE), a-amylase, $\alpha$-glucosidase ${ }^{3}$ and therapeutic effects and protection against several degenerative diseases, especially cancer. ${ }^{4}$ The active ingredients of seaweed can be utilized in a variety of fields, especially in the fields of the pharmaceutical industry, biomedicine, and nutraceuticals, as well as a source of antioxidants. Seaweed as a source of antioxidants has been studied includes seaweed as a cosmetic raw material. ${ }^{5-17}$ Seaweed is also studied as seaweed salt dosage for patients with hypertension ${ }^{18-20}$ while the study as a source of nutraceutical from Sargasum aquifolium extract is conducted by Paradise (2013).
Hypertension has reported in the deaths of 8 million people each year; 1.5 million deaths occur in Southeast Asia. The prevalence of hypertension will continue to increase every year and it is predicted in $202529 \%$ of the population in the world will be affected by hypertension. The diet of salt intake is one of the treatments applied to hypertensive patients, but the weakness is the lack of potassium $(\mathrm{K})$ intake into the body. For a hypertensive condition, potassium $(\mathrm{K})$ has a role in reducing blood pressure. Based on this, hypertensive patients need salts alternatives for a diet of salt intake without lack of potassium (K).

Low-sodium salt is an alternatives product that can be used in hypertensive patients, as a study of salt made from seaweed has been conducted using $U$. lactuca seaweed ${ }^{21}$ and Green seaweeds (C. lentillifera and $H$. opuntia. $)^{12,22}$ Brown seaweed is an alternative in material for low-sodium salt. Minerals and active components in brown seaweed can produce lowsodium salt that had antioxidant activity, but the process of making low-sodium salt from Turbinaria conoides and Padina minor is still very limited, so the aim of this research was to get the characteristics and antioxidant activity of low-sodium salt that can be applied as a salt for hypertensive patients.

\section{MATERIALS AND METHODS}

\section{Materials}

The materials used in this research were T.conoides and P. minor brown seaweed obtained from the Scout Island in Thousand Island Regions, purified 
water, $\mathrm{FeCl}$, (Merck), ethanol PA 99.9\% (Merck), ascorbic acid (Merck), TPTz ((2,4,6-Tris (2- pyridyl)s-triazine) (Sigma-Aldrich), Neocuproine (Sigma-Aldrich), Mg (Merck) powder, amyl alcohol (Merck), Folin-Ciocalteu (Merck), $\mathrm{Na}_{2} \mathrm{CO}_{3}$ (Merck), gallic acid, ascorbic acid (Merck), Trolox (Merck), $\mathrm{CuCl}_{22} \mathrm{H}_{2} \mathrm{O}$ (Merck), ammonium acetate (Merck), $\mathrm{CH}_{3} \mathrm{COOH}$ (Merck), $\mathrm{CH}_{3} \mathrm{COONa}, \mathrm{K}_{2} \mathrm{CrO}_{4}$ (Merck). The analytical devices were water bath (SWBR17), vortex (VM-300), glassware, $\mathrm{pH}$ meter, micropipette (Gilson ${ }^{\circledR}$ ), AAS (Atomic Absorption Spectrophotometer) (Shimatzu AA -700), UV-Vis RS Spectrophotometer (UV-2500), oven (Memmert, Germany), analytic type 210-LC (Adam, United States).

\section{Methods}

This research was conducted in two stages. The first phase includes the sampling, preparation, and identification of the raw materials. The second stage includes the production and characterization of seaweed salts. Characterization of salt consisting of yield analysis, levels of $\mathrm{Na}$ and $\mathrm{K}$, heavy metals, $\mathrm{NaCl}$ and antioxidant activity using Ferric Reducing Antioxidant Power (FRAP) and Cupric Reducing Antioxidant Capacity (CUPRAC) methods.

\section{Sample collection and preparation}

T.conoides and P.minor were obtained from Sulawesi waters and identified in the Marine Bioprospection, Marine Science and Technology Laboratory of Fisheries and Marine Scince Faculty, Bogor Agricultural University. The samples were cleaned from sand and foreign matter and washed the rest of the sample was cut and crushed using a blender until smooth and sieved with a size of 30 mesh using sea water, then placed in a container, while part of the samples was separated for identification purposes soaked in ethanol $70 \%$ and and dried for 3-5 days.

\section{Seaweed salt production}

Seaweed salt was carried out based on the method with modification..$^{23}$ The modifications made are the stirring stage during heating. The process starts with smoothing seaweed using a blender, followed by sifting. It is carried out by mixing seaweed and purified water (1:10) and heated using water bath at temperatures $\left(40\right.$ and $\left.55^{\circ} \mathrm{C}\right)$ during 10 and 30 minutes, stirred. The results were stirred using 500mesh nylon cloth and filter paper, then dried with an oven at $60^{\circ} \mathrm{C}$ for 48 hours.

\section{Levels of the heavy metal and $\mathrm{Na}$ and $\mathrm{K}$ of the functional salt}

Analysis of the heavy metal and $\mathrm{Na}$ and $\mathrm{K}$ levels from functional salts was carried out which is an AAS method (Atomic Absorption Spectrophotometer). ${ }^{24}$ This test uses flame type air- $\mathrm{C}_{2} \mathrm{H}_{2}$ with a length of $\mathrm{Na}$ waves $589.6 \mathrm{~nm}$ and $766.5 \mathrm{~nm}$ and $\mathrm{Na} 0$ detection limit $7143 \mathrm{mg} /$ $\mathrm{kg}$ and $\mathrm{K} 1.0083 \mathrm{mg} / \mathrm{kg}$, while the analysis of heavy metals consists of lead $(\mathrm{Pb})$, copper $(\mathrm{Cu})$, and mercury $(\mathrm{Hg})$ with $\mathrm{Pb}$ wavelength 283.3 $\mathrm{nm}, \mathrm{Cu} 228.8 \mathrm{~nm}$, and $\mathrm{Hg} 253.6 \mathrm{~nm}$ with the limit detection of $\mathrm{Pb}$ at $0.23 \mathrm{mg} / \mathrm{kg}, \mathrm{Cu} 1.2 \mathrm{mg} / \mathrm{kg}$ and $\mathrm{Hg} 0.004 \mathrm{mg} / \mathrm{kg}$.

\section{The seaweed salt $\mathrm{NaCl}$ levels}

Testing the $\mathrm{NaCl}$ level of functional salts was carried out by the Mohr method (modified) based on the Day and Underwood method (1989). $5 \mathrm{~g}$ of the sample was turned into ash, then it was transferred to 250 $\mathrm{mL}$ Erlenmeyer. $1 \mathrm{~mL}$ of $5 \%$ potassium chromate solution was added, followed by titration using silver nitrite solution $0.1 \mathrm{M}$ until orange or orange changes occur. The level of $\mathrm{NaCl}$ can be calculated by the formula:

salt $(\mathrm{NaCl})(\%)=\frac{(\mathrm{T} \times \mathrm{N} \times 58.4)}{\mathrm{w}(\mathrm{mg})} \times 100 \%$

Information: $\mathrm{T}=\mathrm{mL}$ titration

$\mathrm{N}=$ Normality of silver nitrate

$\mathrm{W}=$ sample weight

\section{The seaweed salt iodine levels}

Testing of iodine levels in functional salts was carried out method using ICP-MS. ${ }^{25}$ The sample was weighed in a liner, then concentrated $\mathrm{HNO}_{3}$ added and then pre-digest for 10-15 minutes and continued with the stage of sample destruction. It was cooled and diluted by purified water before analyzed using ICP-MS.

\section{Antioxidant activity using FRAP method}

The functional antioxidant salt activity with the FRAP method was based on modified methods. ${ }^{26}$ FRAP reagent preparation was formed using $300 \mathrm{mM}$ acetate buffer with $\mathrm{pH} 3.6 ; 10 \mathrm{mM}$ TPTZ (2,4,6-tripyridyl-s-triazine) in $40 \mathrm{mM} \mathrm{HCl}$ and $20 \mathrm{mM} \mathrm{F}_{3} \mathrm{Cl}_{3} \cdot 6 \mathrm{H}_{2} \mathrm{O}$ with a ratio of 10:1:1. The absorbance measurement used by mixing $0.1 \mathrm{~mL}$ of sample, $0.6 \mathrm{~mL}$ of distilled water and $3 \mathrm{~mL}$ of FRAP reagent. A mixture of FRAP samples and reagents was mixed in a vortex, then incubated using a water bath at $37^{\circ} \mathrm{C}$ for 30 minutes. Absorbance measurements were carried out at a wavelength of $593 \mathrm{~nm}$. The calibration curve uses the Trolox solution (standard for validation) with various concentrations. Antioxidant capacity is stated in $\mu \mathrm{M}$ trolox/g.

\section{Antioxidant activity using the CUPRAC method}

Samples were made by dissolved $0.25 \mathrm{~m}$ seaweed salt in $1 \mathrm{~mL}$ of distilled water and added with $\mathrm{CuCl}_{2} .2 \mathrm{H}_{2} \mathrm{O} 0.01 \mathrm{M} ; 1 \mathrm{~mL}$ ethanolic neocuproine $0.0075 \mathrm{M} ; 1 \mathrm{~mL}$ of ammonium acetate buffer $\mathrm{pH} 71 \mathrm{M}$ and $0.85 \mathrm{~mL}$ distilled water. A mixture of samples and reagents in the vortex was then incubated within a dark room temperature for 30 minutes. The absorbance measurement is carried out at a wavelength of $450 \mathrm{~nm}$. The calibration curve was made using Trolox solution with various concentrations. Antioxidant capacity is expressed in $\mu \mathrm{M}$ trolox/g. ${ }^{27}$

\section{Data analysis}

The experimental design used was a Completely Randomized Design (CRD). The data obtained were tested with three replication, normality and homogeneity before ANOVA analysis was carried out. Data analysis was performed by Analysis of Variant (ANOVA) at 95\% confidence interval $(\alpha=0.05)$. The significant results then further tested using the Duncan test.

\section{RESULTS}

\section{Characteristics of raw materials}

Identification of the morphology of the raw material is carried out by observing morphological characteristics macroscopically at the Marine Bioprospection, Marine Sciences and Technology Laboratory of IPB. The results of morphological identification were in the class of Phaeophyceae, two family which is Sargassaceae and Dictyotaceae and the species were Turbinaria conoides and Padina minor.

\section{The yield, $\mathrm{Na}$ and $\mathrm{K}$, and $\mathrm{NaCl}$ of the seaweed salt}

The yield analysis of seaweed salts was carried out to see the final weight obtained from the treatment, while the analysis of $\mathrm{Na}$ and $\mathrm{K}$ was carried out to obtain the ratio of Na: $\mathrm{K}$ from the seaweed salts. The parameter ratio of $\mathrm{Na}: \mathrm{K}$ is the main parameter in seaweed salts for the application of a salt diet for hypertensive patients. $\mathrm{NaCl}$ levels in seaweed salts are one of the important elements for its application in hypertensive patients. The results of the analysis of yield, $\mathrm{Na}$ and $\mathrm{K}$, and $\mathrm{NaCl}$ of the seaweed salt can be seen in Table 1 .

Beside the $\mathrm{NaCl}$ levels, the iodine and heavy metal levels $(\mathrm{Hg}, \mathrm{Pb}$, and $\mathrm{Cu}$ ) should fit the standard in the table salt. The levels of iodine and heavy metal of functional salts from $T$. conoides and $P$. minor salts with a heating temperature of $40^{\circ} \mathrm{C}$ for 10 minutes can be seen in Table 2 . 


\section{Antioxidant activity}

Antioxidant activity was determined using two methods with different mechanisms; Ferric Reducing Antioxidant Power (FRAP) and Cupric Reducing Antioxidant Capacity (CUPRAC). The measurement of functional antioxidant salt activity was carried out to determine the antioxidant activity in seaweed salts. Antioxidant activity contained in seaweed salts is one indicator that there is an active component in functional salts. Moreover, antioxidant activity is one of the advantages of seaweed salt compared to table salt and low sodium salts on the market. The antioxidant activity of seaweed salts can be seen in Table 3 .

\section{DISCUSSION/CONCLUSION}

T.conoides habitat is in coral areas with low tides and reef flat areas and the morphology is erect thallus, triangular-small turbinate leaves with a length of $1 \mathrm{~cm}$, attached to stiffed holdfast, forming large and thick colonies and brown. ${ }^{28}$ P. minor seaweed has a flabellate thallus, thin and grows to form colonies with holdfast rhizoid, has a 7-12 lobeline that is yellowish brown in color and has a living habitat in areas with sandy substrates. ${ }^{29}$

Duncan's further test results showed that the interaction of different types of seaweed (T. conoides and P. minor), time (10 and 30 minutes) and temperature $\left(40{ }^{\circ} \mathrm{C}\right.$ and $\left.55^{\circ} \mathrm{C}\right)$ affected the yield of seaweed salts. The average yield of seaweed salts ranges from $20 \%-26 \%$. Generally longer heating times and warmer temperatures can produce higher salt yields, but in industrial applications, shorter heating times and lower temperatures are expected because it can reduce the production costs. Also, the difference in the yield of seaweed salts produced is due to the morphological differences between seaweed species. ${ }^{23}$

Duncan's further test results showed that the interaction of different types of seaweed (T. conoides and P. minor), time (10 and 30 minutes) and temperature $\left(40^{\circ} \mathrm{C}\right.$ and $\left.55^{\circ} \mathrm{C}\right)$ affected the ratio of seaweed salt $\mathrm{Na}: \mathrm{K}$. The average value of the ratio $\mathrm{Na}: \mathrm{K}$ of the functional salt ranges from $0.81-2.54 \mathrm{mg} / \mathrm{g}$. The lowest Na:K ratio was obtained from $T$. conoides seaweed salt with a heating temperature of $40^{\circ} \mathrm{C}$ for 10 minutes. The Ratio of Na:K from T. conoides seaweed salt $(0.81-0.89 \mathrm{mg} / \mathrm{g})$ salt fits the category of functional salt for hypertensive diet, whereas P. minor (2.26$2.54 \mathrm{mg} / \mathrm{g}$ ) only fits the category of table salt. The recommended range of dietary intake Na:K for humans has a ratio between $0.3-1 .{ }^{30,31}$ Salt with a low Na:K ratio and high $\mathrm{K}$ components provide health benefits for consumers. Seaweed salt with "kombu" raw material has a Na:K ratio of $57.7 \mathrm{mg} / \mathrm{g}$, so it belongs to the table salt category. Salt with a low Na:K ratio and higher $\mathrm{K}$ content can provide benefits to consumers because they can replace $\mathrm{NaCl}$ and have an effect on improving health. A health perspective, the low ratio of $\mathrm{Na}: \mathrm{K}$ is related to the application of a salt diet for hypertensive patients. ${ }^{32}$

Duncan's further test results show that the interaction of different types of seaweed (T. conoides and P. minor), time (10 and 30 minutes) and temperature $\left(40^{\circ} \mathrm{C}\right.$ and $\left.55^{\circ} \mathrm{C}\right)$ affect $\mathrm{NaCl}$ levels of the functional salt. Functional salt content ranges $27.74-49.94 \%$. NaCl levels in functional salts compared to table salt is usually classified as having low levels of $\mathrm{NaCl}$. There is two type salt; the first is table salt while the second

Table 1: Yield, $\mathrm{Na}, \mathrm{K}$ and $\mathrm{NaCl}$ of the functional salt.

\begin{tabular}{|c|c|c|c|c|c|c|c|}
\hline Functional salt & $\begin{array}{c}\text { Temperature } \\
\left({ }^{\circ} \mathrm{C}\right)\end{array}$ & $\begin{array}{c}\text { Time } \\
\text { (minute) }\end{array}$ & Yield(\%) & $\begin{array}{c}\mathrm{Na} \\
(\mathrm{mg} / \mathrm{g})\end{array}$ & $\begin{array}{c}\mathrm{K} \\
(\mathrm{mg} / \mathrm{g})\end{array}$ & $\mathrm{Na}: \mathrm{K}$ & $\begin{array}{c}\mathrm{NaCl} \\
(\%)\end{array}$ \\
\hline \multirow{4}{*}{ T. conoides } & \multirow{2}{*}{40} & 10 & $24 \pm 0.69^{\mathrm{bdc}}$ & $61.64 \pm 0.22$ & $76.50 \pm 0.31$ & $0.81^{\mathrm{d}}$ & $46.21 \pm 0.20^{\circ}$ \\
\hline & & 30 & $23 \pm 1.39^{\mathrm{dc}}$ & $63.58 \pm 0.40$ & $71.51 \pm 0.27$ & $0.89^{c}$ & $48.24 \pm 0.42^{\mathrm{b}}$ \\
\hline & \multirow{2}{*}{55} & 10 & $24 \pm 0.77^{\mathrm{d}}$ & $62.75 \pm 0.08$ & $75.28 \pm 0.52$ & $0.83^{\mathrm{d}}$ & $49.94 \pm 0.89^{a}$ \\
\hline & & 30 & $26 \pm 0.38^{\text {bac }}$ & $62.46 \pm 0.21$ & $74.58 \pm 0.50$ & $0.84^{\mathrm{d}}$ & $46.21 \pm 1.53$ \\
\hline \multirow{4}{*}{ P. minor } & \multirow{2}{*}{40} & 10 & $24 \pm 0.58^{\mathrm{dc}}$ & $66.77 \pm 1.95$ & $26.33 \pm 0.03$ & $2.54^{\mathrm{a}}$ & $28.34 \pm 0.10^{\circ}$ \\
\hline & & 30 & $26 \pm 0.37^{\mathrm{e}}$ & $74.88 \pm 0.54$ & $33.10 \pm 0.14$ & $2.26^{\mathrm{b}}$ & $27.91 \pm 0.84^{\circ}$ \\
\hline & \multirow{2}{*}{55} & 10 & $20 \pm 1.68^{\mathrm{a}}$ & $67.09 \pm 0.19$ & $26.59 \pm 0.04$ & $2.52^{\mathrm{a}}$ & $28.77 \pm 0.22^{\circ}$ \\
\hline & & 30 & $26 \pm 1.33^{\text {ba }}$ & $61.93 \pm 0.22$ & $27.08 \pm 0.16$ & $2.29^{\mathrm{b}}$ & $27.74 \pm 1.27^{\circ}$ \\
\hline
\end{tabular}

Notes: The numbers in the same column are followed by the same letters do not differ significantly at the $5 \%$ confidence level (Duncan's multiple tests).

Table 2: lodine and heavy metals content of $T$. conoides and $P$. minor seaweed salt.

\begin{tabular}{|c|c|c|c|}
\hline \multirow{2}{*}{ Parameter (mg/kg) } & \multicolumn{2}{|c|}{ Functional salt } & \multirow{2}{*}{ Standard } \\
\hline & T. conoides & P. minor & \\
\hline Lead $(\mathrm{Pb})$ & $<0.04$ & $<0.04$ & $\max .10 \mathrm{mg} / \mathrm{kg}^{* *}$ \\
\hline Mercury (Hg) & $<0.002$ & $<0.002$ & $\max .0 .1 \mathrm{mg} / \mathrm{kg}^{* *}$ \\
\hline Copper $(\mathrm{Cu})$ & 0.96 & 0.99 & $\max .10 \mathrm{mg} / \mathrm{kg}^{*}$ \\
\hline Iodine (I) & 240.00 & 64.10 & $\min .30 \mathrm{mg} / \mathrm{kg}^{* *}$ \\
\hline
\end{tabular}

Notes: ${ }^{*}\left(\right.$ SNI 2000), ${ }^{* *}($ SNI 2010).

Table 3: Antioxidant activity of seaweed salt.

\begin{tabular}{|c|c|c|c|c|}
\hline Seaweed & Temperature $\left({ }^{\circ} \mathrm{C}\right)$ & Time (minutes) & $\begin{array}{c}\text { FRAP antioxidant activity } \\
(\mu \mathrm{M} \text { trolox } / \mathrm{g})\end{array}$ & $\begin{array}{c}\text { CUPRAC antioxidant activity } \\
(\mu \mathrm{M} \text { trolox } / \mathrm{g})\end{array}$ \\
\hline \multirow{4}{*}{ T. conoides } & \multirow{2}{*}{40} & 10 & $40.00 \pm 0.96$ & $98.50 \pm 0.07$ \\
\hline & & 30 & $39.12 \pm 1.00$ & $99.02 \pm 0.37$ \\
\hline & \multirow{2}{*}{55} & 10 & $54.33 \pm 1.68$ & $113.62 \pm 0.27$ \\
\hline & & 30 & $55.31 \pm 1.54$ & $113.95 \pm 0.27$ \\
\hline \multirow{4}{*}{ P. minor } & \multirow{2}{*}{40} & 10 & $18.19 \pm 0.23$ & $40.05 \pm 0.04$ \\
\hline & & 30 & $19.40 \pm 0.04$ & $48.31 \pm 0.11$ \\
\hline & \multirow{2}{*}{55} & 10 & $05.05 \pm 0.41$ & $51.69 \pm 0.18$ \\
\hline & & 30 & $24.67 \pm 0.15$ & $53.05 \pm 0.29$ \\
\hline
\end{tabular}


is diet salt. ${ }^{32}$ Table salts have a minimum requirement of $94 \% \mathrm{NaCl}$ concentration, while for a diet salt the maximum value is $60 \%$.

T. conoides functional salt can be used as an alternative for hypertensive patients because it contains a $\mathrm{Na}: \mathrm{K}$ ratio that meets the standard as diet salt, while $P$. minor functional salt can be used as a table salt. $T$. conoides functional salt and $P$. minor can be used as an alternative due to its standard and benefit for health from the lower $\mathrm{Na}$ : $\mathrm{K}$ ratio, low $\mathrm{NaCl}(<60 \%)$, more iodine $(>30 \mathrm{mg} / \mathrm{kg})$, and with only a trace of heavy metal.

The phenol compounds antioxidants will be oxidized in the presence of light, heat, and oxygen. Besides that, the phenol in functional salts has acidic, volatile, and it is sensitive to the light and oxygen. Phenol levels in a material will decrease with the treatment of washing, boiling, and further processing. ${ }^{33}$

A seaweed salt FRAP antioxidant activity was $18.19-55.31 \mu \mathrm{M}$ trolox/g belongs to moderate antioxidant capacity. The compound belongs to very strong antioxidant activity if the antioxidant capacity value is more than $500 \mu \mathrm{mol} \mathrm{Fe} / \mathrm{g}$, while strong if the antioxidant capacity is 100 $500 \mu \mathrm{mol} \mathrm{Fe} / \mathrm{g}$, moderate if the antioxidant capacity is $10-100 \mu \mathrm{mol}$ $\mathrm{Fe}^{2} / \mathrm{g}$, and weak if the antioxidant capacity is $<10 \mu \mathrm{mol} \mathrm{Fe} / \mathrm{g} .{ }^{34}$ The result from the heating temperature of $55^{\circ} \mathrm{C}$ for 30 minutes has the highest antioxidant activity $(55,31 \mu \mathrm{M}$ trolox $/ g$ ). FRAP (Ferric Reducing Antioxidant Power) is a method of determining an antioxidant activity to measure the ability of antioxidants to reduce $\mathrm{Fe}^{3+}$ in complexes $\mathrm{Fe}$ ${ }^{3+}$-TPTZ becomes $\mathrm{Fe}^{2+}$-TPTZ by donating electrons.

The CUPRAC seaweed salt antioxidant activity was $40.05-113.95$ $\mu \mathrm{M}$ trolox / g. The result from a heating temperature of $55^{\circ} \mathrm{C}$ for 30 minutes has the highest antioxidant activity (113. $95 \mu \mathrm{M}$ trolox/g). The CUPRAC (Cupric Reducing Antioxidant Capacity) method is based on electron transfer and is considered a good indicator of total antioxidant ability. ${ }^{35}$ Antioxidant activity in seaweed such as Turbinaria sp. and $P$. polysiphonia has an important role in the aging process, anti-inflammatory, anti-bacterial, anti-fungal, cytotoxic, anti-malarial, antiproliferative, and anti-cancer. ${ }^{36}$

Seaweed T. conoides and P. minor could be used as raw material for the preparation of low sodium seaweed salts with antioxidant activity. A heat treatment temperature of $40{ }^{\circ} \mathrm{C}$ for 10 minutes of T. conoides produced seaweed salts that were low in $\mathrm{Na} \mathrm{K}$ ratio and heavy metals but high in iodine, $\mathrm{NaCl}$, and antioxidant activity so it could be used as raw material for dietary salt. While $P$. minor could be used as raw material for table salt preparations because it produces a $\mathrm{Na}: \mathrm{K}$ ratio that exceeds the standard of diet salt.

\section{ACKNOWLEDGEMENTS}

Authors gratefuly acknowledge the Research Grant from Indonesian Ministry of Higher Education and Technology PTUPT 2019 No. 3/E1/ KP.PTNBH/2019 to Prof. Dr. Nurjanah.

\section{REFERENCES}

1. Kkp.go.id [database on the Internet]. National seaweed cultivation. Jakarta (ID) : Ministry of Maritime Affairs and Fisheries. [Cited 2017 Oct 19]. Available from : http://kkp.go.id

2. Deyab M, Elkatony T, Ward F. Qualitative and quantitative analysis of phytochemical studies on brown seaweed Dictyota dichotoma. IJEDR. 2016;4(2):674-8.

3. Nagappan H, Pee PP, Kee SHY, Ow JT, Yan SW, Chew LY, et al. Malaysian brown seaweeds Sargassum siliquosum and Sargassum polycystum: low density lipoprotein (LDL) oxidation, angiotensin converting enzyme (ACE), $\alpha$-amylase and $\alpha$-glucosidase inhibition activities. Food Res. 2017;99(2):950-8.

4. Padua D, Rocha E, Gargiulo D, Ramos AA. Bioactive compounds from brown seaweeds: phloroglucinol, fucoxanthin and fucoid as promising therapeutic agents against breast cancer. Phytochem Lett. 2015;14:91-8.

5. Nurjanah, Jacoeb AM, Hidayat $T$, Hazar S, Nugraha R. Antioxidant activity, total phenol content and bioactive components of lindur leave ( Bruguierra gymnorrhiza ). AJFST. 2016;2(4):65-70.
6. Luthfiyana N, Nurjanah, Nurilmala M, Anwar E, Hidayat $\mathrm{T}$. The ratio of grass pulp aut Eucheuma cottonii and Sargassum sp. as a sunscreen cream formula. JPHPI. 2016;19(3):183-95.

7. Maharany F, Nurjanah, Suwandi R, Anwar E, Hidayat T. Bioactive compound content of Padina australis seaweed and Eucheuma cottonii as raw material for sunscreen creams. JPHPI. 2017;20(1):10-7.

8. Yanuarti R, Nurjanah, Anwar E, Hidayat T. Phenolic profile and antioxidant activity of Turbinaria conoides and Eucheuma cottonii seaweed extract. JPHPI. 2017;20(2):230-7.

9. Dolorosa MT, Nurjanah, Purwaningsih S, Anwar E, Hidayat T. The bioactive compounds of seaweed Sargassum plagyophyllum and Eucheuma cottonii are raw materials for skin lightening creams. JPHPI. 2017;20(3):633-44.

10. Nurjanah, Abdullah A, Nufus C. Characteristics of Ulva lactuca salt from Sekotong waters in West Nusa Tenggara for hypertensive patients. JPHPI 2018; $21(1): 109-17$

11. Nurjanah, Luthfiyana $N$, Hidayat T, Nurilmala M, Anwar E. Utilization of seaweed porridge Sargassum sp. and Eucheuma cottonii as cosmetic in protecting skin. IOP Conf. Series: Earth and Environmental Science ; 2018 Oct 9-10 ; Bogor, Indonesia: The $3^{\text {rd }}$ EIW; 2019.

12. Nufus $C$, Abdullah A, Nurjanah. Characteristics of green seaweed salt as alternative salt for hypertensive patients. IOP Conf. Series: Earth and Environmental Science. 2018 Oct 9-10; Bogor, Indonesia: The $3^{\text {rd }}$ EIW; 2019.

13. Dolorosa MT, Nurjanah, Purwaningsih, Anwar E, Hidayat T. Tyrosinase inhibitory activity of Sargassum plagyophyllum and Eucheuma cottonii methanol extracts. IOP Conf. Series: Earth and Environmental Science. 2018 Oct 9-10; Bogor Indonesia: The $3^{\text {rd }}$ EIW; 2019.

14. Gazali M, Zamani NP, Nurjanah. The potency of green algae Chaetomorpha crassa Agardh as antioxidant agent from the coastal of Lhok Bubon, West Aceh. IOP Conf. Series: Earth and Environmental Science. 2018 Oct 9-10; Bogor, Indonesia: The $3^{\text {rd }}$ EIW; 2019.

15. Nurjanah, Suwandi R, Anwar E, Maharany F, Hidayat T. Characterization and formulation of sunscreen from seaweed Padina australis and Euchema cottoni slurry. IOP Conf. Ser.: Earth Environ. Sci. 2019 Aug 5-6; Bogor, Indonesia: The $4^{\text {th }}$ EIS; 2019

16. Dolorosa MT, Nurjanah, Purwaningsih, Anwar E. Utilization of Kappaphycus alvarezii and Sargassum plagyophyllum from Banten as cosmetic creams. IOP Conf. Ser.: Earth Environ. Sci. 2019 Aug 5-6; Bogor, Indonesia:The 4th EIS; 2019

17. Nurjanah, Nurilmala M, Hidayat T, Sudirjo F. Characteristics of seaweed as raw materials for cosmetics. Aquat. Procedia. 2016;7(1):177-80

18. Diachanty S, Nurjanah, Abdullah A. Antioxidant activity of various types of brown seaweed from the waters of the Thousand Islands. JPHPI. 2017;20(2):305-18.

19. Nufus C, Nurjanah, Abdullah A. Characteristics of green seaweed from the waters of the Thousand Islands and Sekotong West Nusa Tenggara as antioxidants. JPHPI. 2017;20(3):620-31.

20. Nurjanah, Abdullah A, Hidayat T, Fachrozan R. 2018 ${ }^{\text {b }}$. Characteristics of seaweed porridge Sargassum sp. and Eucheuma cottonii as raw materials for lip balm. IOP Conference Series: Earth and Environmental Science. 2017 Nov 6-8 Universitas Putra Malaysia, Serdang, Selangor, Malaysia : 2018.

21. Nurjanah, Aprilia BE, Fransiskayana A, Rahmawati M, Nurhayati T. Senyawa bioaktif rumput laut dan ampas teh sebagai antibakteri dalam formula masker wajah. JPHPI. 2018 ; 20(2):305-18.

22. Kurniawan R, Nurjanah, Jacoeb AM, Abdullah A, Pertiwi RM. Karakteristik garam fungsional dari rumput laut hijau. JPHPI. 2019;22(3):573-80.

23. Magnusson M, Carl C, Mata L, Nys R, Paul NA. Seaweed salt from U/va: a nove first step in a cascading biorefinery model. Algal Research. 2016;16:308-16.

24. Association of Analytical Chemist Publisher. Official methods of analysis of the official analytical chemist association. Virginia (US): The Association of Official Analytical Chemist, Inc; 2005.

25. Association of Analytical Chemist Publisher. Official methods of analysis of the official analytical chemist association. Virginia (US): The Association of Official Analytical Chemist, Inc; 2012

26. Benzie IFF, JJ Strain. The ferric reducing ability of plasma (FRAP) as a measurement of antioxidant power: the FRAP assay. Anal. 1996;239(1):70-6.

27. Apak R, Guclu K, Ozyurek M, Celik SE. Mechanism of antioxidant capacity assays and the CUPRAC (Cupric lon Reducing Antioxidant Capacity) assay. MICROCHIM ACTA. 2008;160(1):413-19

28. Algaebase.org. Taxonomy browser. [Update; 2004 Sept 23; Cited 2017 Sept 09]. Available from : http://www.algaebase.org/search/species

29. Tampubolon A, Gerung GS, Wagey B. Macro algal diversity in lasige Island lagoon, Tagulandang sub-district, Sitaro Regency. JPLT. 2013;2(1):35-43.

30. World Health Organization. Guideline: Potassium Intake for Adults and Children. Australia (AUS) : Australian Government Department of Health and Ageing National Health and Medical Research Council; 2012. 
31. Peng $Y$, Xie E, Zheng K, Fredimoses $M$, Yang $X$, Zhou $X$, et al. Nutritional and chemical composition and antiviral activity of cultivated seaweed Sargassum naozhouense Tseng et Lu. Mar Drugs. 2013;11(1):20-32.

32. Indonesian National Standard. SNI 3556: 2010 iodized consumption salt. Jakarta (ID): National Standardization Agency; 2010

33. Trissanthi CM, Susanto WH. Effect of citric acid concentration and heating duration on the chemical and organoleptic characteristics of alang-alang syrup ( Imperata cylindrica ). JPA. 2016;4(1):180-9.
34. Wong CC, Li HB, Cheng KW, Chen F. A systemic survey of antioxidant activity of 30 Chinese medicinal plants using ferric reducing antioxidant power assays. Food Chem. 2006;97(4):705-11.

35. Karahalil FY, Sahin H. Phenolic composition and antioxidant capacity of cherry laurel (Laurocerasus officinalis Roem.) sampled from Trabzon region, Turkey. Afr. 2011;10(72):16293-99.

36. Kelman D, Posner EK, McDermid KJ, Tabandera NK, Wright PR, et al. Antioxidant activity of Hawaiian Marine Algae. Mar Drugs. 2012;10(2):403416.

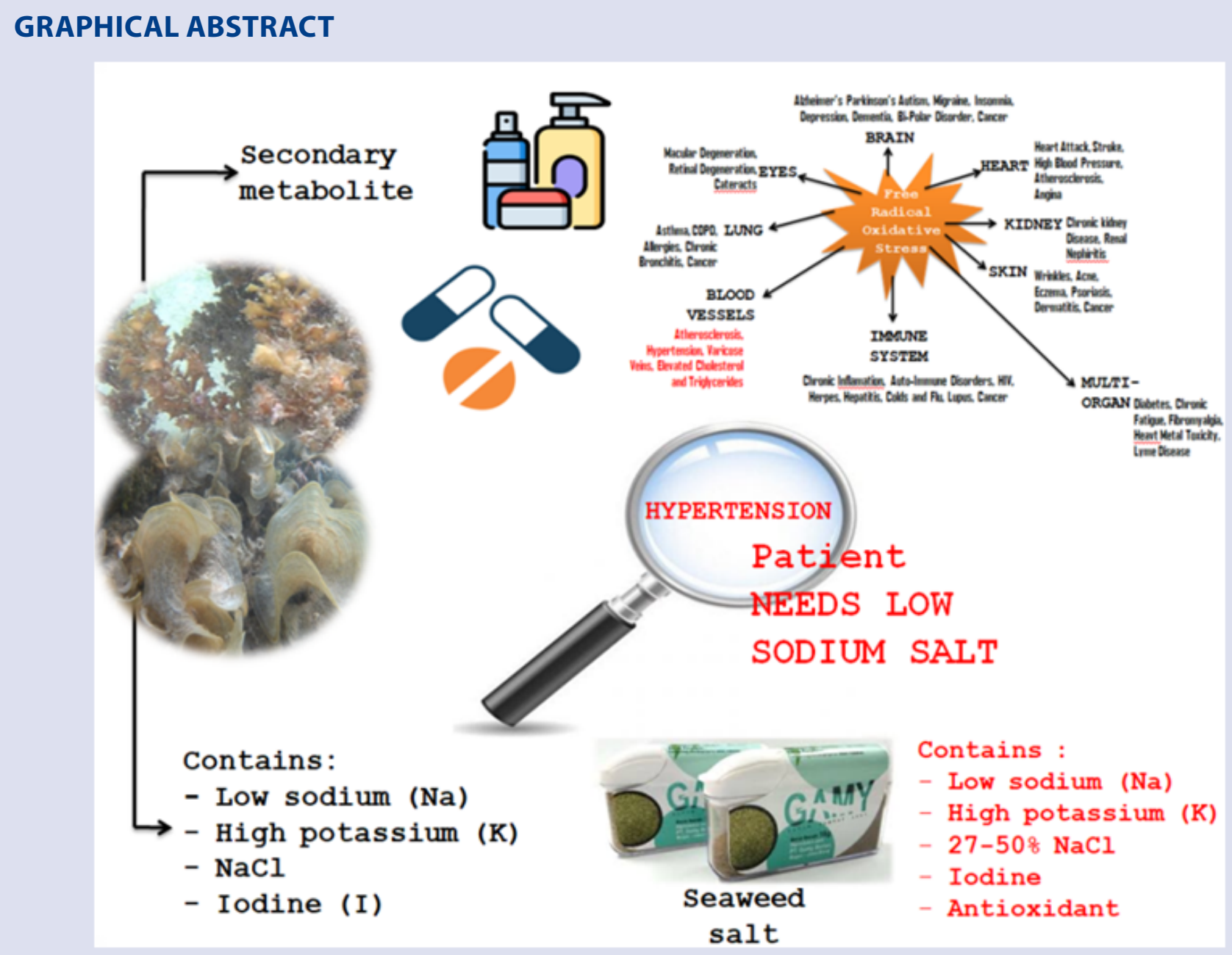

\section{ABOUT AUTHORS}

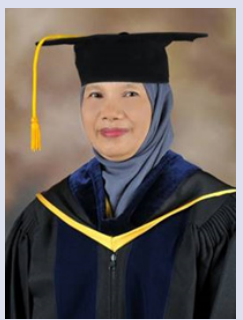

Nurjanah: Professor (Lecturer and Researcher) in Aquatic Product Technology Department, Faculty of Fisheries and Marine Sciences, Bogor Agricultural University (IPB University), Dramaga 16680, West Java, Indonesia. Her research interest: Seaweed bioprospecting and cosmeceuticals.

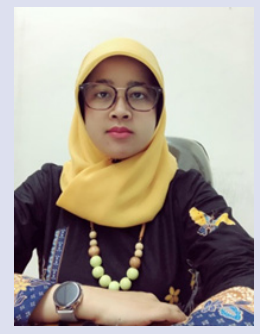

Asadatun Abdullah: Associate Professor (Lecturer and Researcher) in Aquatic Product Technology Department, Faculty of Fisheries and Marine Sciences, Bogor Agricultural University (IPB University), Dramaga 16680, West Java, Indonesia. Her research interest: Marine bioprospecting and biochemistry. 


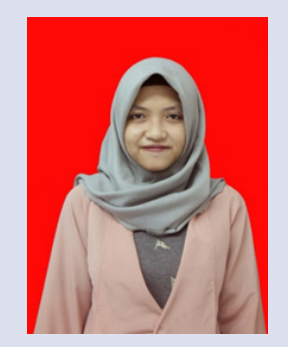

Seftylia Diachanty: Lecturer and Researcher in Fisheries Product Technology Department, Faculty of Fisheries and Marine Sciences, Mulawarman University.

Cite this article: Nurjanah, Abdullah A, Diachanty S. Characteristics of Turbinaria conoides and Padina Minor As Raw Materials For Healthy Seaweed Salt. Pharmacogn J. 2020;12(3):624-9. 